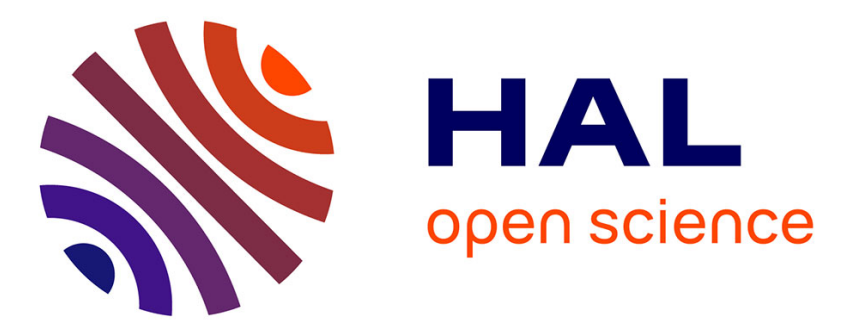

\title{
Influence of some food additives on IgG plasma concentrations in newborn calves fed an immunoglobulin solution extracted from colostrum
}

Jf Grongnet, Gt dos Santos, M Piot, R Toullec

\section{- To cite this version:}

Jf Grongnet, Gt dos Santos, M Piot, R Toullec. Influence of some food additives on IgG plasma concentrations in newborn calves fed an immunoglobulin solution extracted from colostrum. Le Lait, 1996, 76 (3), pp.303-309. hal-00929487

\section{HAL Id: hal-00929487 \\ https://hal.science/hal-00929487}

Submitted on 1 Jan 1996

HAL is a multi-disciplinary open access archive for the deposit and dissemination of scientific research documents, whether they are published or not. The documents may come from teaching and research institutions in France or abroad, or from public or private research centers.
L'archive ouverte pluridisciplinaire HAL, est destinée au dépôt et à la diffusion de documents scientifiques de niveau recherche, publiés ou non, émanant des établissements d'enseignement et de recherche français ou étrangers, des laboratoires publics ou privés. 


\title{
Influence of some food additives on IgG plasma concentrations in newborn calves fed an immunoglobulin solution extracted from colostrum
}

\author{
JF Grongnet ${ }^{1}$, GT Dos Santos 2 , M Piot ${ }^{3}, \mathrm{R}$ Toullec $^{4}$ \\ 'Laboratoire de sciences animales, Ensar, 65, rue de Saint-Brieuc, 35042 Rennes; \\ ${ }^{2}$ Universitad Estadual de Maringa, Parana, Brasil; ${ }^{3}$ Laboratoire de technologie laitière, Inra; \\ ${ }^{4}$ Laboratoire du jeune ruminant, Inra, 65, rue de Saint-Brieuc, 35042 Rennes, France
}

(Received 6 March 1995 ; accepted 2 November 1995)

\begin{abstract}
Summary - A lot of newborn ruminants have no free access to their mother's colostrum, due to various reasons. For them, colostro-replacers are now on the market. These products contain immunoglobulins but their capacity to pass through the intestinal wall is often doubtful. So, an experiment has been designed to test the influence of three supplements on the absorption of immunoglobulins extracted from colostrum by ultrafiltration. Fifty newborn calves were divided into five groups of ten. The first group received three meals of colostrum, exactly 2,10 , and $18 \mathrm{~h}$ after birth. According to the same kinetics, the four other groups received the same amount of immunoglobulins but previously extracted from colostrum and diluted in a saline solution. The diets given to the last three groups were supplemented with isobutyric acid, caseino-macropeptide and colostrum extract, respectively. Immunoglobulins extracted from colostrum were badly absorbed compared with control colostrum diet. In spite of liberal supply of immunoglobulins given soon after birth, the IgG plasmatic levels of the calves fed immunoglobulin solution remained below what is usually admitted as a good passive immunity. All the three additives were unable to improve the immunoglobulins' absorption.
\end{abstract}

calf / birth / colostrum / immunoglobulin

Résumé - Influence de quelques additifs sur les taux plasmatiques d'immunoglobulines G mesurés chez le veau nouveau-né après ingestion d'immunoglobulines extraites de colostrum. De nombreux ruminants nouveau-nés n'ont pas accès au colostrum de leur mère, pour des raisons diverses. À leur intention, des substituts de colostrum sont maintenant commercialisés. Ils sont riches en immunoglobulines, dont l'aptitude à être absorbées par l'intestin du jeune animal, n'est pas solidement établie. Nous avons testé l'influence de trois additifs, sur l'absorption des immunoglobulines extraites du colostrum par ultrafiltration. Cinquante veaux nouveau-nés de race Holstein, ont été divisés en cinq groupes de dix. Le premier a reçu trois repas de colostrum 2, 10 et $18 \mathrm{~h}$ après la naissance, très exactement. Suivant une cinétique identique, les quatre autres ont reçu la même quantité d'immunoglobulines extraites du colostrum et remises en solution saline. Les régimes des trois derniers lots ont été supplémentés en acide isobutyrique, caséino-macropeptide ou extrait protéique de colostrum. Les immunoglobulines extraites du colostrum ont été beaucoup moins bien absorbées que les immunoglobulines restées dans leur milieu d'origine. Malgré une administration 
abondante effectuée très précocement après la naissance, les concentrations plasmatiques en lgG obtenues sont restées inférieures au taux de $10 \mathrm{~g} / \mathrm{L}$ qui est habituellement considéré comme nécessaire pour assurer la protection immunitaire du nouveau-né. Les trois additifs testés se sont montrés sans effet positif sur l'absorption des immunoglobulines.

veau / naissance / colostrum / immunoglobuline

\section{INTRODUCTION}

Due to the absence of immunoglobulin placental transfer, young ungulates are born agammaglobulinemic (Levieux, 1984) and, consequently, are highly sensitive to infections. To protect them, a sufficient amount of colostrum well provided with immunoglobulins should be given as soon as possible (Dardillat et al, 1978). However, for many newborn calves, lambs, kids or foals, several reasons may impair colostrum intake: insufficient production in case of multiple births, acute mastitis, lack of adequate maternal behaviour mostly at first parturition, etc. These difficulties seem to be smoothed out by giving frozen colostrum and more recently, colostrum replacers, which are essentially issued from the newly established colostrum industry. Nevertheless, it is important to be very cautious regarding these nutritional specialities because of low IgG plasma concentrations frequently obtained (Zaremba et al, 1993). Drying standard colostrum collected from farm to farm, leads to products which are often poorly provided with immunoglobulins because farmers are tempted to deliver not only first milking colostrum but also those from second or third milking. In order to preserve an adequate concentration of immunoglobulins, liquid reconstitution before supplying the newborn, with a reduced amount of water, is attractive. This is not suitable, resulting in a beverage too viscous to be delivered via a bucket or an artificial teat. Therefore, before drying, removal of the major part of fat and other proteins is needed. Extraction of immunoglobulins from colostrum, followed by concentration, may be considered but according to Grongnet et al (1986), in such conditions, immunoglobulins appear to be poorly absorbed by the intestine of the newborn calf. That's why an experiment was made to test the ability of some food additives to improve the absorption efficiency of immuglobulins extracted from colostrum. Three products were used. Two of them, isobutyric acid (IA) (Hardy, 1969) and freeze dried colostrum extract (FDCE) (Balfour and Comline, 1962) have already been favourably tested in related conditions. The third one, caseinomacropeptide (CMP) could reduce gastric secretion (Chernikov et al, 1974), thus limiting abomasal denaturation of immunoglobulins.

\section{ANIMALS, MATERIALS AND METHODS}

\section{Animals}

Fifty newborn Holstein calves ( 41 male, 9 female) were separated at birth from their dams, housed in individual pens and affected, birth after birth, by systematic circular permutation (table I) to one of five treatments: colostrum, immunoglobulin solution either alone or supplemented with IA, CMP or FDCE. All the animals were born spontaneously, at term and without dystocia. Calving was often slightly accelerated by a mild traction exerted on the forelimbs of the animals. No chemical compound was used to facilitate parturition.

\section{Diets}

First milking colostra were obtained from about 40 cows of the ENSAR dairy herd. Colostra were frozen just after milking, all thawed, at the end of the calving season, pooled and frozen again, for $20 \%$ of the total amount, by aliquot fractions 
Table I. Body weight and sex of 50 newborn calves fed colostrum or immunoglobulin solution. Poids vif et sexe de 50 veaux nouveau-nés alimentés avec du colostrum ou une solution d'immunoglobulines.

\begin{tabular}{lccc}
\hline Diets & $\begin{array}{c}\text { Bodyweight } \\
(x \pm \text { sem/kg) }\end{array}$ & Male & Female \\
\hline Colostrum & $42.7 \pm 2.2$ & 8 & 2 \\
$\begin{array}{l}\text { Immunoglobulin solution (IS) } \\
\text { Immunoglobulin solution + isobutyric acid } \\
(0.5 \%) \text { (IS + IA) }\end{array}$ & $39.7 \pm 2.4$ & 7 & 3 \\
$\begin{array}{l}\text { Immunoglobulin solution + } \\
\text { caseinomacropeptide (0.4\%) (IS + CMP) }\end{array}$ & $43.4 \pm 1.4$ & 7 & 3 \\
$\begin{array}{l}\text { Immunoglobulin solution + freeze dried } \\
\text { colostrum extract (IS + FDCE) }\end{array}$ & $39.7 \pm 2.2$ & 10 & 1 \\
\hline
\end{tabular}

of $1 \mathrm{~L}$. The immunoglobulin solution (IS) was prepared with the remaining $80 \%$, according to figure 1. Diafiltration was stopped when immunoglobulin $\mathrm{G}$ (IgG) concentration reached the initial colostrum concentration, ie, $44 \mathrm{~g} / \mathrm{L}$. FDCE issued from the first permeate, was prepared during the same technological operations (fig 1), in order to collect all the low molecular mass soluble proteins, present in colostrum at the beginning. Before use, FDCE was added to immunoglobulin solution in a proportion suited to restore the initial colostrum concentrations.

Aliquot fractions of colostrum and immunoglobulin solution were thawed in a warm water bath and supplemented if necessary with IA, CMP or FDCE, just before feeding the animals. Exactly 2, 10 and $18 \mathrm{~h}$ after birth, the calves were fed either colostrum or one of the immunoglobulin solutions. The meals were three times delivered at the rate of $25 \mathrm{~g} / \mathrm{kg}$ body weight and given in a bucket fitted with a teat at the bottom. In order to equalize the quantities of immunoglobulin ingested, in case of carefully recorded obvious inappetence, repeated pressure on the teat to force deglutition or oesophageal intubation were practised.

\section{Measurements, analysis and statistics}

Blood was collected in heparinised vials by puncture of a jugular vein just before each meal and
$26 \mathrm{~h}$ after birth. It was immediately centrifuged and resulting plasma was frozen at $-20^{\circ} \mathrm{C}$ till analysis. IgG concentrations were measured on a immunonephelemeter Behring for plasma, colostrum and immunoglobulin solution according to Lebreton et al (1981) with an anti IgG $(\mathrm{H}+\mathrm{L})$ Behring rabbit immunserum. During the extraction process, HPLC on gel filtration column (GF 250 , DuPont) was used in order to control real time the evolution of immunoglobulin concentration in the solution. Rectal temperature was noted before each blood sampling. Anova and test were used for statistical analysis.

\section{RESULTS}

\section{Weight, vitality, appetite and health of calves}

Vitality was excellent during the whole experimental period except for two animals suffering from transient general atony after the second meal. They recovered about $4 \mathrm{~h}$ later.

Colostrum was very well accepted for the three meals but not the immunoglobulin solutions, whose acceptability depended on the nature of the additive. Highest refusal occurred with isobutyric acid: $30 \%$ for the first meal, $80 \%$ for the second and $70 \%$ for 

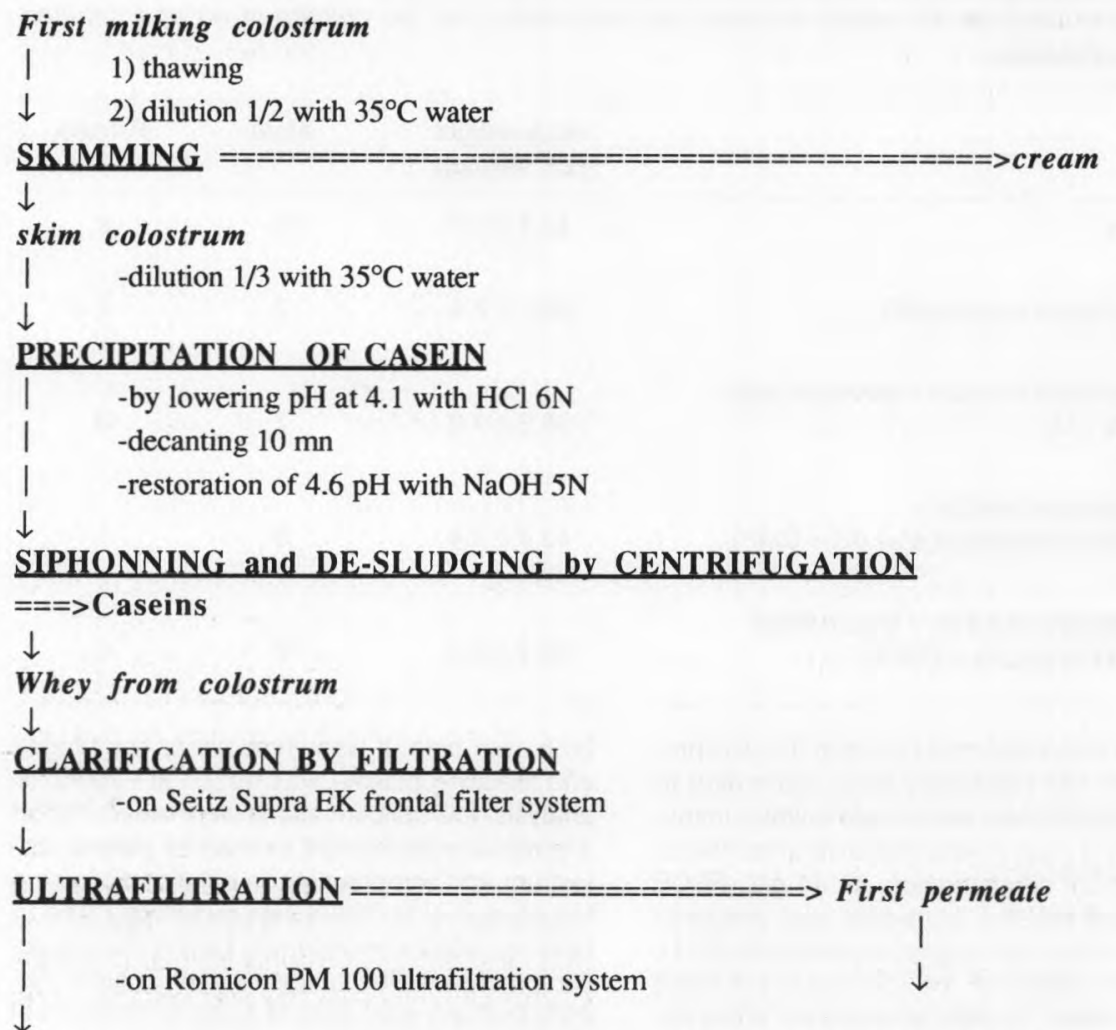

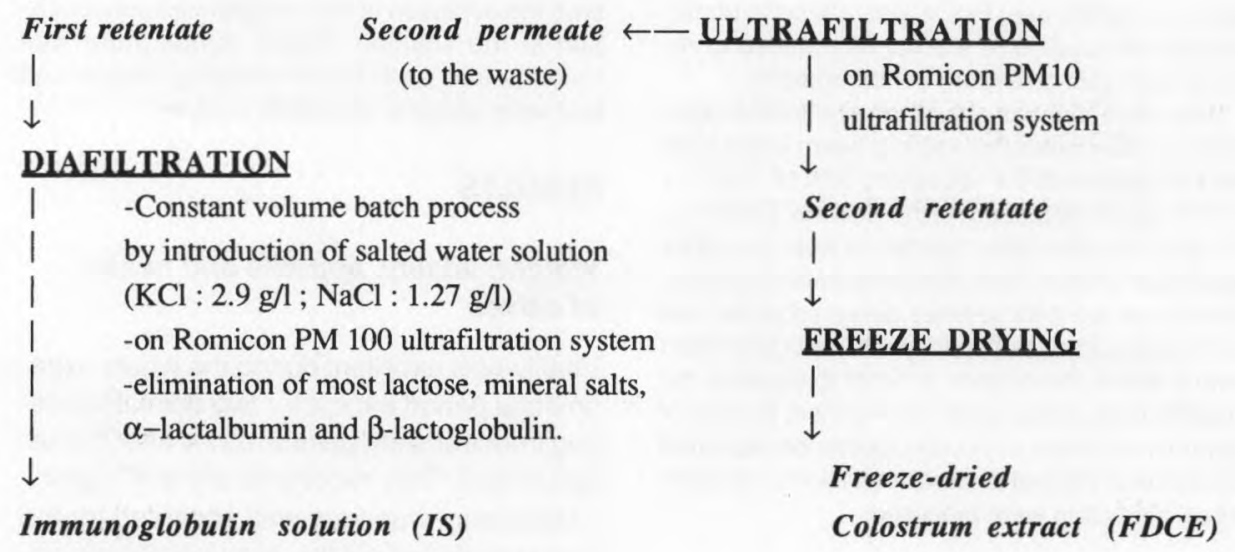

Fig 1. Extraction process of immunoglobulin from colostrum. Procédé d'extraction des immunoglobulines à partir du colostrum. 
Table II. Postnatal evolution of rectal temperature $\left({ }^{\circ} \mathrm{C}\right)$ of 50 newborn calves fed colostrum or immunoglobulin solution $(x \pm S D)$.

Évolution postnatale de la température rectale $\left({ }^{\circ} \mathrm{C}\right)$ de 50 veaux nouveau-nés alimentés avec du colostrum ou une solution d'immunoglobulines (moyenne \pm écart type).

\begin{tabular}{lcccc}
\hline Groups & \multicolumn{5}{c}{ Time after birth $(h)$} \\
\cline { 2 - 5 } & 2 & 10 & 18 & 26 \\
\hline Colostrum & $37.9 \pm 0.4$ & $38.2 \pm 0.1$ & $38.7 \pm 0.1$ & $38.7 \pm 0.1$ \\
IS & $38.0 \pm 0.4$ & $38.0 \pm 0.3$ & $38.2 \pm 0.2$ & $38.6 \pm 0.2$ \\
IS + IA & $37.6 \pm 0.2$ & $38.0 \pm 0.1$ & $38.2 \pm 0.2$ & $38.3 \pm 0.1$ \\
IS + CMP & $37.8 \pm 0.2$ & $38.0 \pm 0.1$ & $38.3 \pm 0.1$ & $38.7 \pm 0.2$ \\
IS + FDCE & $38.2 \pm 0.2$ & $38.0 \pm 0.2$ & $38.4 \pm 0.2$ & $38.7 \pm 0.1$ \\
& & & & \\
\hline
\end{tabular}

the last. For immunogolulin solution alone, it was $30,70,40 \%$ and only $0,30,20 \%$ for CMP and FDCE, respectively. The strict rule used to affect the animals to the various treatments, led to slight and non-significant differences in average weight of the five groups and to slightly unbalanced sex-ratios.

\section{Rectal temperature and IgG plasma concentrations}

Rectal temperature (table II) rose slightly and significantly from the beginning and stabilized thereafter. No significant differences were observed among treatments.

Before the first meal, IgG plasma concentrations (table III) were below the detection level of the nephelemeter and considered equal to zero. For all treatments, feeding triggered an obvious increase which lasted during the whole experimental period except for IA group which exhibited the same values at $18 \mathrm{~h}$ and $26 \mathrm{~h}$ of life. The colostrum group differs strongly from all the other groups characterized by dramatically weak

Table III. Postnatal evolution of plasma IgG concentrations ( $\mathrm{g} / \mathrm{L}$ ) of 50 calves fed colostrum or immunoglobulin solution $(x \pm S D)$.

Évolution post-natale de la concentration plasmatique en immunoglobulines G de 50 veaux nouveau-nés alimentés avec du colostrum ou une solution d'immunoglobulines (moyenne \pm écart type).

\begin{tabular}{lcccc}
\hline Groups & \multicolumn{4}{c}{ Time after birth $(h)$} \\
\cline { 2 - 5 } & 2 & 10 & 18 & 26 \\
\hline Colostrum & 0 & $5.8 \pm 2.6^{\mathrm{A}}$ & $11.0 \pm 3.7^{\mathrm{A}}$ & $12.8 \pm 4.4^{\mathrm{A}}$ \\
IS & 0 & $2.3 \pm 0.7^{\mathrm{Ba}}$ & $4.2 \pm 2.8^{\mathrm{Bab}}$ & $5.6 \pm 3.7^{\mathrm{Ba}}$ \\
IS + IA & 0 & $1.4 \pm 0.9^{\mathrm{Bb}}$ & $2.8 \pm 1.9^{\mathrm{Ba}}$ & $3.3 \pm 2.6^{\mathrm{Bb}}$ \\
IS + CMP & 0 & $1.9 \pm 1.4^{\mathrm{Ba}}$ & $4.2 \pm 2.6^{\mathrm{Bab}}$ & $4.9 \pm 2.8^{\mathrm{Bab}}$ \\
IS + FDCE & 0 & $2.1 \pm 1.2^{\mathrm{Ba}}$ & $4.9 \pm 1.6^{\mathrm{Bb}}$ & $5.6 \pm 2.8^{\mathrm{Ba}}$
\end{tabular}

For every time, values with different capital letters are significantly different at $P<0.001$; values with different small letters are significantly different at $P<0.05$.

Pour chaque temps, les valeurs avec des lettres majuscules différentes sont significativement différentes àp $<0,001$; les valeurs avec lettres minuscules différentes sont significativement différentes à $\mathrm{p}<0,05$. 
values: always lower than $6 \mathrm{~g} / \mathrm{L}$ instead of $12.8 \mathrm{~g} / \mathrm{L}$ in colostrum group $26 \mathrm{~h}$ after birth.

\section{DISCUSSION}

A concentration of $44 \mathrm{~g} / \mathrm{L} \mathrm{IgG}$ in the first milking colostrum pool used here is weak when compared with $100 \mathrm{~g} / \mathrm{L}$ recorded by Levieux (1984). But his result was obtained in Charolais cows producing a scarce but highly concentrated colostrum. Today, in high-producing Holstein cows, 40 to $50 \mathrm{~g} / \mathrm{L}$ may be considered as an average (Grongnet, unpublished data; Levieux, personal communication).

Good general vitality emphasizes that the immunoglobulin solution, except for it's disappointing bad absorption efficiency and supplemented or not, was harmless, as opposed to the results obtained by Grongnet et al (1986). Similar evolution of rectal temperature in all groups shows that the low amount of energy provided by immunoglobulin solution did not impair thermoregulation.

Colostrum-fed animals exhibit maximal IgG plasma concentrations lower than those recorded in quite similar conditions by Grongnet et al (1986) but in agreement with Stott et al (1979), Gay et al (1983) and enough for ensuring a satisfactory protection. Taking into account such weak levels registered with the immunoglobulin solution, it can be said, first of all, that oesophageal intubation needed by frequent inappetence cannot impair so strongly the absorption mechanism. This particular way of colostrum administration has been systematically and successfully used by some authors (Al-Jawad and Lees, 1985). Birth weight differences can no more be involved: they are very small among groups and colostrum-fed animals are neither the heaviest nor the lightest. Besides, influence of birthweight on Ig absorption has always been recorded as slight or negligible $(\mathrm{Be}$ kele et al, 1992). It is the same for influence of sex (Villette et Levieux, 1981; Donovan et al, 1986; Bekele et al, 1992). Finally, the composition of the solution seems to be the only factor involved in the insufficient absorption.

Additives were all ineffective. Isobutyric acid was even injurious, disagreeing with the results of Hardy (1969) who observed an improvement with this compound under quite similar experimental conditions. CMP is a 64-aminoacid peptide, released in the abomasum, following action of chymosin on k-casein. In the preruminant calf, CMP enters rapidly the duodenum (Guilloteau et al, 1987). Vasilevskaya et al (1977) established, in the dog, that CMP injection restricted gastric secretions, previously stimulated by histamine or gastrin C-terminal tetrapeptide. As reduction of hydrochloric secretion, pepsin and other proteases would have a favourable effect on acquisition of passive immunity in mammals (Chernikov et al, 1974), addition of CMP to immunoglobulin solution was attractive but this hypothesis was not confirmed by the results presented here. FDCE was tested with reference to Balfour and Comline (1962). A positive effect was obtained by these authors with a low molecular mass protein, from colostral origin but not identified. Our negative result seems to indicate that this component has a molecular mass below $10000 \mathrm{kDa}$, level of cut-off of the half-permeable membrane here used to retain our FDCE (fig 1).

Colostrum has an antitryptic activity, exerting probably a protective effect on IgG in the gut. Grongnet et al (1986) have established that this beneficial property was preserved in an immunoglobulin solution prepared in the same way as described here. Therefore, large differences in absorption efficiency do not appear to be related to variations of antitryptic activity.

Many hypotheses can be advanced to explain these low IgG plasmatic levels. Lack of energy must be considered. Immunoglobulin solution was free of fat and lactose. Grongnet et al (1986) found that the addition of milk powder to such a solution im- 
proved IgG plasma concentrations in newborn calves. Secondly, it must be taken into account that before joining blood, a great part of IgG is found in the lymphatic system (Kiriyama, 1992), a way also used by lipids. This may suggest that IgG leaves the enterocytes via a mechanism involving lipids.

Colostrum is a complex biological medium still insufficiently known. Precise physico-biochemical conditions seem to be needed for an efficient IgG transport from intestinal lumen to lymph and blood. Additional research is still required to ensure valuable utilization of colostrum substitutes in field conditions.

\section{REFERENCES}

Al-Jawad AB, Lees JL (1985) Effects of ewe's colostrum and various substitutes on the serum immunoglobulin concentration, gut closure process and growth rate of lambs. Anim Prod 40,123-127

Balfour WE, Comline RS (1962) Acceleration of the absorption of unchanged globulin in the new-born calf by factors in colostrum. J Physiol 160, 234-257

Bekele T, Otesile EB, Kasali OB (1992) Influence of passively acquired colostral immunity on neonatal lamb mortality in Ethiopian highland sheep. Small Ruminant Res 9, 209-215

Chernikov MP, Stan EY, Shygin GK, Vasilevskaya LS (1974) Problem of biological activity of CMP (in Russian). Vop Pitan 2, 21-25

Dardillat J, Trillat G, Larvor P (1978) Colostrum immunoglobulin concentrations in cows: relationship with their calf mortality and with the colostrum quality of their female offspring. Ann Rech Vet 9, 375-384

Donovan GA, Badinga L, Collier RJ, Wilcox CJ, Braun RK (1986) Factors influencing passive transfer in dairy calves. J Dairy Sci 69, 754-759
Gay CG, McGuire TC, Parish SM (1983) Seasonal variation in passive transfer of immunoglobulin $\mathrm{G} 1$ to the newborn calves. J Am Vet Med Assoc 183, 566568

Grongnet JF, Grongnet-Pinchon E, Levieux D, Piot M, Lareynie J (1986) Newborn calf intestinal absorption of immunoglobulins extracted from colostrum. Reprod Nutr Dev 26, 731-743

Guilloteau P, Chayvialle JA, Mendy F, Roger L, Toullec R, Bernard C, Mouats A, Faverdin P (1987) Effet du CMP sur la sécrétion gastrique et les taux circulants d'hormones digestives chez le veau préruminant Reprod Nutr Dev 27, 287-288

Hardy RN (1969) The influence of specific chemical factors in the solvent on the absorption of macromolecular substances from the small intestine of the newborn calf. J Physiol 204, 607-632

Kiriyama $H$ (1992) Enzyme linked immunosorbent assay of colostral lgG transported into lymph and plasma in neonatal pigs. Am J Physiol 263, R976-980

Lebreton JP, Joisel F, Boutleux S, Lannuzel B, Sauger $F(1981)$ Dosage immunonéphélométrique des immunoglobulines $\mathrm{G}$ dans le lait de vache. I. Mise au point technique du dosage. Lait 61, 465-480

Levieux D (1984) Transmission de l'immunité passive

- colostrale: le point des connaissances. In: Physiologie et pathologie périnatales chez les animaux de ferme (Jarrige R, ed) INRA, Paris

Stott GH, Marx DB, Menefee BE, Nightengale GT (1979) Colostral immunoglobulin transfer in calves. 1: Period of absorption. J Dairy Sci 62,1632-1638

Vasilevskaya LS, Stan EY, Chernikov MP, Shlyhin GH (1977) Inhibitory action of CMP on gastric secretion stimulated by some humoral components. (in Russian). Vop Pitan 4, 21-24

Villette Y, Levieux D (1981) Etude de l'influence de l'âge de la mère sur la transmission de l'immunité passive colostrale chez l'agneau. Ann Rech Vet 12, 227-232

Zaremba W, Guterbock WM, Holmberg CA (1993) Efficacy of dried colostrum powder in the prevention of disease in neonatal holstein calves. J Dairy Sci 76, $831-836$ 